\title{
Lessepsian migration and parasitism: richness, prevalence and intensity of parasites in the invasive fish Sphyraena chrysotaenia compared to its native congener Sphyraena sphyraena off Tunisia
}

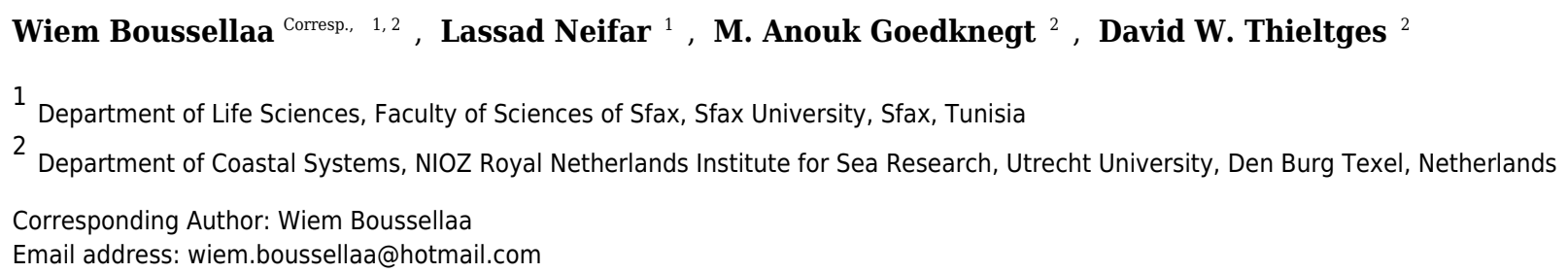

Background Parasites can play various roles in the invasion of non-native species, but these are still understudied in marine ecosystems. This also applies to invasions from the Red Sea to the Mediterranean Sea via the Suez Canal, the so-called Lessepsian migration. In this study, we investigated the role of parasites in the invasion of the Lessepsian migrant Sphyraena chrysotaenia in the Tunisian Mediterranean Sea. Methods We compared metazoan parasite richness, prevalence and intensity of $S$. chrysotaenia (Perciformes: Sphyraenidae) with infections in its native congener $S$. sphyraena by sampling these fish species at seven locations along the Tunisian coast. Additionally, we reviewed the literature to identify native and invasive parasite species recorded in these two hosts. Results Our results suggest the loss of at least two parasite species of the invasive fish species. At the same time, the Lessepsian migrant has co-introduced three parasite species, during the initial migration to the Mediterranean Sea, that are assumed to originate from the Red Sea of which only one parasite species has been reported during the spread to Tunisian waters. In addition, we found that the invasive fish has acquired six parasite species that are native in the Mediterranean Sea. However, parasite richness, prevalence and intensity were overall much lower in the invasive compared to the native fish host in the Mediterranean Sea. Discussion These results suggest that the Lessepsian migrant may affect native fish hosts by potentially altering the dynamics of native and invasive parasite-host interactions via parasite release, parasite co-introduction and parasite acquisition. They further suggest that the lower infection levels in the invasive fish may result in a competitive advantage over native fish hosts (enemy release hypothesis). This study demonstrates that cross-species comparisons of parasite infection levels are a valuable tool to identify the different roles of parasites in the course of Lessepsian migrations. 
1 Lessepsian migration and parasitism: richness, prevalence and intensity of parasites in the

2 invasive fish Sphyraena chrysotaenia compared to its native congener Sphyraena sphyraena

3 off Tunisia

4

5

6 Wiem Boussellaa 1,2), Lassad Neifar 1), M. Anouk Goedknegt 2), David W. Thieltges 2)

7

8

$9{ }^{1}$ Department of Life Sciences, Faculty of Sciences of Sfax, and Sfax University, Sfax, Tunisia

10

11

${ }^{2}$ Department of Coastal Systems, Royal Netherlands Institute for Sea Research, and Utrecht

12 University, Den Burg Texel, Netherlands

13

14

15

Corresponding author: Wiem Boussellaa

17

E-mail: wiem.boussellaa@hotmail.com

18

ORCID: 0000-0002-6728-9262

19

20

21

22 


\section{Abstract}

25 Background Parasites can play various roles in the invasion of non-native species, but these are still understudied in marine ecosystems. This also applies to invasions from the Red Sea to the Mediterranean Sea via the Suez Canal, the so-called Lessepsian migration. In this study, we investigated the role of parasites in the invasion of the Lessepsian migrant Sphyraena chrysotaenia in the Tunisian Mediterranean Sea.

Methods We compared metazoan parasite richness, prevalence and intensity of S. chrysotaenia (Perciformes: Sphyraenidae) with infections in its native congener S. sphyraena by sampling these fish species at seven locations along the Tunisian coast. Additionally, we reviewed the literature to identify native and invasive parasite species recorded in these two hosts.

Results Our results suggest the loss of at least two parasite species of the invasive fish species. At the same time, the Lessepsian migrant has co-introduced three parasite species, during the initial migration to the Mediterranean Sea, that are assumed to originate from the Red Sea of which only one parasite species has been reported during the spread to Tunisian waters. In addition, we found that the invasive fish has acquired six parasite species that are native in the Mediterranean Sea. However, parasite richness, prevalence and intensity were overall much lower in the invasive compared to the native fish host in the Mediterranean Sea.

41 Discussion These results suggest that the Lessepsian migrant may affect native fish hosts by potentially altering the dynamics of native and invasive parasite-host interactions via parasite

43 release, parasite co-introduction and parasite acquisition. They further suggest that the lower

44 infection levels in the invasive fish may result in a competitive advantage over native fish hosts 45 (enemy release hypothesis). This study demonstrates that cross-species comparisons of parasite 
46 infection levels are a valuable tool to identify the different roles of parasites in the course of

47 Lessepsian migrations.

48 Introduction

49 One of the potential explanations for the establishment and subsequent spread of invasive 50 species in marine and other ecosystems is the enemy release hypothesis (Elton, 1958; Keane \&

51 Crawley, 2002). This hypothesis states that invasive species may gain a competitive advantage

52 over native species by losing all or part of their natural enemies, such as predators and parasites,

53 during the invasion process. For parasites, such a release or reduction has been documented for a

54 wide range of host taxa including marine species (Torchin, Lafferty \& Kuris, 2001; Keane \&

55 Crawley, 2002; Torchin et al., 2003; Torchin \& Mitchell, 2004; Blakeslee, Fowler \& Keogh,

56 2013). However, invasive hosts do not necessarily lose all their native parasites during an

57 invasion, but can often co-introduce parasites to their non-indigenous range (Lymbery et al.,

58 2014). The likelihood of this co-introduction depends, among others, on the host specificity and

59 life cycle of the respective parasite species. Generalist parasites which infect a larger range of

60 host species and parasites with direct life cycles are more likely to be co-introduced than highly

61 specific parasites or parasites with complex life cycles (i.e., depending on several sequential

62 different host species; Torchin, Lafferty \& Kuris, 2002; Poulin \& Morand, 2004; Lymbery et al.,

63 2014). In the new range, co-introduced parasites may also infect native hosts (parasite spillover;

64 Prenter et al., 2004, Kelly et al., 2009), with potentially serious impacts on native species and

65 ecosystems (emerging diseases; Daszak, Cunningham \& Hyatt, 2000). Finally, invasive species

66 can also acquire native parasites from native host species. This parasite acquisition may have

67 deleterious effects on naïve invasive host species ('increased susceptibility hypothesis' sensu

68 Colautti et al., 2004), but may also ultimately amplify native parasite population sizes, resulting 
69 in increased parasite loads in native hosts, a phenomenon which is referred to as parasite

70 spillback (Kelly et al., 2009). While many of these mechanisms may result in a competitive

71 advantage for invasive over native species, the magnitude of this advantage will depend on the

72 actual difference in parasite infection levels between invasive and native hosts. Several studies comparing infection levels in invasive and introduced hosts (community studies or cross-species comparisons; sensu Colautti et al., 2004; Torchin \& Mitchell, 2004) have shown that infection levels are often lower in invasive host species (Georgiev et al., 2007; Dang et al., 2009; Roche et al., 2010; Gendron, Marcogliese \& Thomas, 2012). However, such cross-species comparisons of infection levels in invasive and native competitors are surprisingly scarce (Goedknegt et al., 2017). In addition, our knowledge on the role of parasites in biological invasions in general is still limited, especially in the marine realm (Vignon \& Sasal, 2010; Goedknegt et al., 2016). This also applies to species invasions in the Mediterranean Sea, an ecosystem with an extraordinarily high rate of species introductions, with more than 1000 alien species listed (Bilecenoglu et al., 2013). Especially via the Suez Canal, which was opened in 1869, many benthic invertebrates and fish species have migrated from the Indian Ocean over the Red Sea to the Mediterranean Sea, a massive human-initiated invasion referred to as Lessepsian migration (sensu Por, 1978). Despite this high migration rate and the resulting high number of species introductions, parasitological investigations of invasive species have been surprisingly rare in this region (Pérez-del-Olmo, Kostadinova \& Gibson, 2016) and have only focused on a few host species such as a portunid crab (Galil \& Innocenti, 1999), the Lessepsian fishes Siganus spp. (Diamant, 2010), Fistularia commersonii (Merella et al., 2016), Etrumeus golanii (Boussellaa et al., 2016) and Lagocephalus sceleratus (Bakopoulos, Karoubali \& Diakou, 2017). Initially, 18 species of parasites spread over four taxonomic groups (Monogenea, Crustacea, Protozoa and 
92 Digenea) had been recognized as Lessepsian migrants which have been co-introduced with their

93 hosts to the Mediterranean Sea (Zenetos et al., 2008), and more recently this list has been

94 updated by the addition of many other parasite species (Diamant, 2010, Merella et al., 2016).

95 Given that there are many Lessepsian migrants that have never been under parasitological

96 investigation, the actual list of co-introduced parasite species is likely to be much longer. In

97 addition, invasive hosts may have acquired native parasite species but whether the resulting

98 parasite loads of hosts are actually lower, equal to or higher than the ones in native species in the

99 Mediterranean Sea has scarcely been studied to date.

100 In the present study, we investigated metazoan parasite infections in the Lessepsian

101 migrant fish Sphyraena chrysotaenia Klunzinger, 1884, along the Tunisian coast in the central

102 Mediterranean Sea. This fish species was first recorded in the eastern Mediterranean Sea in 1931

103 (Spicer, 1931) and has since then spread westwards, after which it was reported for the first time

104 at the Tunisian coast in 2002 (Bradai et al., 2002). It is now a relatively common piscivorous fish

105 of about $20-25 \mathrm{~cm}$ length, living in the pelagic and demersal zones to a depth of $50 \mathrm{~m}$ in inshore

106 waters where it is captured by local artisanal fisheries (Golani \& Ben Tuvia, 1995; Wadie \&

107 Riskhallah, 2001; Zouari-Ktari, Bradai \& Bouain, 2009). A cross-species comparison of the

108 parasite communities was carried out considering the parasite richness and levels of infection in

109 the invasive fish and in the congeneric native one Sphyraena sphyraena Linnaeus, 1758. This

110 native fish species is usually larger than the invasive species (30-60 cm length) but has an

111 overlapping prey spectrum (Kalogirou et al., 2012), lives in the same habitats and is also used by

112 local fisheries (Relini \& Orsi Relini, 1997; Allam, Faltas \& Ragheb, 2005). By sampling

113 invasive (S. chrysotaenia) and native (S. sphyraena) fish hosts along the Tunisian coast and by

114 conducting an additional parasitological literature survey, we aimed to answer the following 
115 specific research questions: 1) Is there evidence that $S$. chrysotaenia experienced a release from

116 its native parasites from the Red Sea?, 2) did S. chrysotaenia co-introduce parasites from the Red

117 Sea and/or did it acquire native parasites from the Mediterranean Sea? and 3) how do parasite

118 richness, prevalence and intensity in the invasive $S$. chrysotaenia compare with those in the

119 native S. sphyraena?

120 Material and methods

121 Fish sampling

122 Between October 2012 and July 2015, a total of 107 specimens of Sphyraena sphyraena

123 (native fish) and 148 specimens of Sphyraena chrysotaenia (invasive fish) were collected at

124 seven fishing localities along the Tunisian coast (off the cities of Sfax, Kerkennah, Skhira,

125 Chebba, Zarat, Zarzis and Sayeda; Fig. 1, Table 1). Fish were mostly bought from local

126 fishermen operating landing trawlers along the Tunisian coast at a depth of about $30 \mathrm{~m}$. In

127 addition, some specimens were recovered from artisanal inshore fishery of Kerkennah and

128 Chebba. Only adult individuals were examined, with total lengths of $25.7-42.7 \mathrm{~cm}$ for $S$.

129 sphyraena and 18.5-26.2 cm for S. chrysotaenia. Samples were kept fresh or were deep-frozen in

130 individual plastic bags at $-10^{\circ} \mathrm{C}$, until examination in the laboratory. After defrosting, all fish

131 individuals were identified to species level using Whitehead et al. (1984) and Fisher et al. (1987)

132 and examined for parasites as described below. During our study, Faculty of Sciences of Sfax

133 provided full approval for this purely observational research.

135 Parasite sampling

136 We only checked for metazoans parasites, as this was the focus of our study. Fish skin, fins,

137 nasal pits, eyes and buccal cavities were thoroughly examined for the presence of ectoparasites 
138 under a stereomicroscope with incident light. Gill arches were separated by incision, and then

139 placed in petri dishes filled with sea water and examined for the presence of ectoparasites.

140 Internal organs (stomach, pyloric caeca, intestines, heart, liver, spleen, gall bladder and gonads)

141 were separated and individually examined for the presence of endoparasites. Platyhelminthes

142 were fixed between a slide and coverslip with 70\% ethanol. Fixed specimens were stained with

143 Semichon's acetic carmine, dehydrated using a graded ethanol series then cleared in clove oil

144 and mounted in Canada balsam. Other parasites (copepods, isopods, nematodes and annelids)

145 were directly fixed in 70\% ethanol for later examination. Parasites were identified to the lowest

146 taxonomic level possible using Gibson et al. (2002) for Digenea, Neifar (1995) and Theisen et al.

147 (2017) for Monogenea, Euzet (1994) for Cestoda, Berland (1961) and Petter \& Maillard (1988)

148 for Nematoda and the keys of Kabata (2003) for Copepoda.

150 Literature review

151 We searched literature databases (Host-Parasite database from the Natural History Museum in

152 London, Web of Science, Google Scholar) for published records of additional parasite species

153 from the Mediterranean Sea and the Red Sea. Search strings included the species names and the

154 different parasite taxa. In addition, we searched the reference sections of publications and our

155 own reference collections for potential further studies reporting parasite infections in the two 156 fish.

158 Statistical analyses

As sampling effort differed between native $(n=107)$ and invasive fish hosts $(n=148)$, we produced rarefaction curves to identify the level of dependence of species accumulation on 
161 sampling effort. Sample-based rarefaction curves were computed based on sample sizes at the 162 different locations (Gotelli \& Colwell 2001) using Estimates S 9.1.0 (Colwell, 2013). Based

163 recommendations by Walther \& Morand (1998) in regard to parasites, we used the

164 nonparametric species estimator Chao2 for our rarefaction analyses. This species estimator

165 algorithm uses the frequency of unique species in samples to estimate the number of missing 166 species in a population (Chao, 2005).

167 We used general linear models (GLMs) to test for statistical differences between the fish 168 species and among locations in parasite richness of individual fish (Poisson distribution; $\mathrm{n}=$ 169 255), infection status of individual fish (infected or uninfected; binomial distribution; $\mathrm{n}=255$ )

170 and intensity of infected fish (negative binomial distribution; $\mathrm{n}=127$ ). In each model, we added

171 host species and location as fixed factors and an interaction term. As the parasite fauna of the

172 two host species was very different, we used the total infection status and intensity of parasite

173 species per host species to compare infection levels between hosts. Although this procedure may

174 obscure the potentially different effects on hosts exerted by different parasite species, this

175 lumping procedure still allows for an approximate comparison of overall infection levels. We did 176 not add fish size as a covariate in the models because preliminary analyses using GLMs did not 177 show an effect of fish size on any of the response variables. All statistical models were run using 178 the statistical software environment R v3.3.0. (R Development Core Team 2016).

\section{Results}

181 After the dissections of 107 individuals of the native Sphyraena sphyraena and 148 individuals 182 of the invasive $S$. chrysotaenia caught along the coast of Tunisia, ten different parasite species 183 infecting the two fish were found. Our additional literature survey added another ten parasite 
184 species records from the Mediterranean or Red Sea to the total parasite species list of both fish 185 species (Table 2).

186

187 Parasite release

188 In total, five parasite species were collected from the Lessepsian migrant Sphyraena

189 chrysotaenia in Tunisian coastal waters (Table 2). In addition, the literature survey indicated that 190 four other parasite species have been found in this invasive host species elsewhere in the

191 Mediterranean Sea (Table 2). Hence, S. chrysotaenia is infected by at least nine parasite species in

192 its invaded range. In its native range, the Red Sea, two parasite species of S. chrysotaenia have been

193 reported in the literature (Table 2). In addition, three of the parasite species found in S. chrysotaenia

194 in the Mediterranean Sea most likely originate from Red Sea, although published records are not 195 available. This suggests that the Lessepsian migrant harbours at least five parasite species in its 196 native range, the Red Sea (Table 2).

197

198

$\underline{\text { Parasite co-introduction and acquisition }}$

199 The examination and the literature survey revealed that the Lessepsian migrant S. chrysotaenia is 200 infected by three parasite species in the Mediterranean Sea that are assumed to originate from the Red Sea (Table 2). Our results further revealed that the Lessepsian migrant S. chrysotaenia has 202 acquired six native parasite species in the Mediterranean Sea (Table 2). Five of those species were found in our survey in Tunisian coastal waters and a fifth species had been noted in $S$. chrysotaenia elsewhere in the Mediterranean Sea (Table 2).

205

206

Comparison with the native congeneric species Sphyraena sphyraena 
The native congeneric species Sphyraena.sphyraena was infected with six parasite

208

209

210

211

212

213

214

215

216

217

218

219

220

221

222

223

224

225

226

227

228

229

species in Tunisian coastal waters and four additional species have been described in the literature (Table 2). Of all these parasite species, only one was shared with the introduced fish host $S$. chrysotaenia, the presumably native isopod Gnathia sp.. None of the parasites that were co-introduced by the Lessepsian migrant have been found to infect the native congeneric host species (Table 2).

In general, the rarefaction curves did not reach asymptotic levels in the two congeneric host species, indicating that a higher sampling effort may reveal more (albeit rare) parasite species in Tunisian coastal waters (Fig. 2). The species accumulation curves further indicate that the total parasite species richness at a given sampling effort could be higher in the native than in the invasive host species. This was also reflected in the mean parasite richness per individual fish found at the seven locations, which was generally significantly higher in the native $S$. sphyraena than in the invasive $S$. chrysotaenia $\left(\mathrm{GLM}: \beta=0.705, \mathrm{SE}=0.586, \Delta_{\text {Deviance }}=110.655, \mathrm{df}=253, \mathrm{p}\right.$ $<0.001$; Fig. 3). However, at some locations this pattern was reversed, resulting in a significant interaction term $\left(\Delta_{\text {Deviance }}=3.470, \mathrm{df}=241, \mathrm{p}<0.01 ;\right.$ Fig. 3$)$.

Likewise, the infection status of fish hosts was generally significantly higher in the native S. sphyraena than in the invasive $S$. chrysotaenia $\left(\mathrm{GLM}: \beta=1.966, \mathrm{SE}=1.201, \Delta_{\text {Deviance }}=\right.$ 162.599, $\mathrm{df}=247, \mathrm{p}<0.001 ;$ Fig. $4 \mathrm{a})$. This was consistent over all locations as there was no significant difference in overall infection status between locations $(\mathrm{p}=0.294$; Fig.4a). However, due to the absence of infections at two locations, there was a significant interaction term $\left(\Delta_{\text {Deviance }}=168.19, \mathrm{df}=241, \mathrm{p}<0.05:\right.$ Fig. $\left.4 \mathrm{a}\right)$. Mean intensity of infections also differed between host species, with the native fish being infected with higher numbers of parasites than the invasive fish host (GLM: $\beta=0.337, \mathrm{SE}=0.586, \Delta_{\text {Deviance }}=35.420, \mathrm{df}=119, \mathrm{p}<0.001$; Fig. 
$2304 \mathrm{~b})$. There was also a significant effect of location on overall infection intensities $\left(\Delta_{\text {Deviance }}=\right.$

$23126.295, \mathrm{df}=120, \mathrm{p}<0.001)$, with location 1 showing much lower values than the other locations

232 (Fig. 4b). However, there was no significant interaction between location and host species $(\mathrm{p}=$ $2330.249)$.

234

235 Discussion

236 Based on samples from the Tunisian coast and additional literature data, our analyses indicate that

237 the invasive Lessepsian migrant $S$. chrysotaenia lost two parasite species during its introduction to 238 the Mediterranean Sea, but that the invasive fish also co-introduced parasites from the Red Sea 239 and acquired one generalist parasite from native fish hosts in the Mediterranean Sea (Table 2).

240 However, parasite richness and infection levels were overall much lower in the invasive

241 compared to the native fish host, suggesting a potential competitive advantage for the Lessepsian

242 migrant.

\section{Parasite release}

244 In its native range (the Red Sea), the invasive S. chrysotaenia harbours at least five parasite 245 species (Table 2). Of these five parasite species, only three species have been recorded in the 246 Mediterranean Sea and only one in Tunisian coastal waters (Table 2). Hence, two parasite 247 species, the digenean Bucephalus sphyraenae and the monogenean Pseudolamellodiscus 248 sphyraenae have been lost in the process of the initial invasion to the Mediterranean Sea. Two 249 other species, the copepod Nothobomolochus denticulatus and the isopod Cymothoa indica, have 250 been observed elsewhere in the Mediterranean Sea, but not in Tunisian coastal waters (Table 2), 251 suggesting a loss of these parasite species in the course of the spread to the Tunisian coast. This 252 loss of several natural parasite species is consistent with the enemy release hypothesis (Torchin 
253 et al., 2003; Blakeslee, Fowler \& Keogh, 2013) and has previously been observed in other

254 Lessepsian migrant fish, the rabbitfish Siganus rivulatus (see Diamant, 1989) and partially

255 reported from the bluespotted cornet fish Fistularia commersonii (see Merella et al., 2016).

256

257 Several processes may be responsible for a loss of parasites in the course of passing the Suez

258 Canal "filter" or "bottleneck" (Por, 1978). First of all, parasites may not be able to cope with the

259 environmental conditions in the canal or in the Mediterranean Sea and do not survive to the

260 migration the new ecosystem. This negative impact of environmental conditions should be

261 particularly relevant for ectoparasites, which are more exposed to the external environment than

262 endoparasites, and may explain the loss of the monogenean Pseudolamellodiscus sphyraenae.

263 Second, parasites may survive the passage through the canal, but, in the case of parasites with

264 complex life cycles, they may be unable to find suitable intermediate hosts in the recipient

265 ecosystems. In general, parasite co-introductions seem to be more common in parasites with

266 simple life cycles as the necessity for all hosts being present for parasites with complex life

267 cycles makes invasions less likely (Lymbery et al., 2014; Goedknegt et al., 2016). Such a lack of

268 suitable hosts may explain the loss of the trematode Bucephalus sphyraenae as trematodes are

269 generally very host specific in respect to their first intermediate gastropod host (Poulin \& Cribb,

270 2002; Galaktionov \& Dobrovolskij, 2003). The respective gastropod host species that serves as

271 first intermediate host for B. sphyraenae is not known, but a (co-)introduction of snails is

272 unlikely because of their relatively reduced mobility. Finally, even in the case that all potential

273 hosts are present in the new environment, the number of introduced parasite individuals may be

274 too low to maintain a viable population. In general, propagule pressure is known to be a strong

275 determinant of invasion success in biological invasions in general (Wonham et al., 2000; Forsyth 
276 \& Duncan, 2001; Rouget \& Richardson, 2003; Colautti et al., 2004). In the case of parasites,

277 propagule pressure may be low if infection levels are low in the native region, reducing both the

278 chances for a co-introduction and for developing viable populations after introduction to the

279 Mediterranean Sea. This could explain the loss of infections with the monogenean

280 Pseudolamellodiscus sphyraenae as this species may show only very low infection levels in its

281 native range. These different mechanisms are not only acting during the passage of Lessepsian

282 migrants through the Suez Canal, but also during the spread in the Mediterranean Sea after the

283 initial introduction. This is illustrated by the copepod Nothobomolochus denticulatus and the

284 isopod Cymothoa indica which have both been co-introduced into the Mediterranean Sea and

285 have been found on S. chrysotaenia in the eastern Mediterranean Sea (Trilles \& Bariche, 2006;

286 El-Rashidy \& Boxshall, 2012), but not in Tunisian waters (our study).

287

Parasite co-introduction

The present results and literature review revealed that the Lessepsian migrant $S$.

chrysotaenia is infected by three parasite species in the Mediterranean Sea that most likely

originate from the Red Sea (Table 2). One of these species, the monogenean parasite

Pseudempleurosoma sp., was recorded in our study in Tunisian waters. There are several reasons why we believe that this parasite species has been co-introduced to the Mediterranean Sea

(although this still needs to be confirmed by records from its presumed native range).

First of all, the species has not been recorded in any native fish species in the Mediterranean Sea in earlier studies, although fish parasites are relatively well studied in this coastal ecosystem (Oliver, 1987; Neifar \& Euzet, 2007; Pérez-del-Olmo, Kostadinova \& Gibson, 2016; Chaabane et al. 2016a; Chaabane et al. 2016b). Second, the genus Pseudempleurosoma, represented by four 
299 species in the literature, seems to have a strict specificity to its host (Santos, Mourão \&

300 Cárdenas, 2001), suggesting that it can only be co-introduced with its host. Finally, with their

301 direct life cycles, monogeneans are likely to be introduced and persist in a new environment.

302 Especially in gregarious fish such as the Sphyraenidae, the transmission of parasites with a direct

303 life cycle can easily take place so that the lifecycle can be maintained in the new environment

304 after an initial introduction.

305

306 The two other parasite species, the copepod Nothobomolochus denticulatus and the isopod 307 Cymothoa indica are less host specific and have also been found on other fish species from the

308 Red Sea (El-Shahawy \& Desouky, 2010). These two species have not been recorded in our study

309 in Tunisian waters but have been reported elsewhere in the Mediterranean Sea (Trilles \&

310 Bariche, 2006; El-Rashidy \& Boxshall, 2012). Both species have not been recorded in any native

311 fish before their invasion but are considered to be co-introduced by the describing authors

312 (Trilles \& Bariche, 2006; El-Rashidy \& Boxshall, 2012). However, as there are no published

313 records of the two species available from the native range of the host, their invasive status still

314 has to be confirmed. Both species have not (yet) been co-introduced into Tunisian coastal waters

315 in the course of the spread of their hosts after the initial introduction in the Mediterranean Sea,

316 probably due some of the mechanisms discussed above.

317

318 Parasite acquisition

319 Besides being infected with co-introduced parasites, our study also revealed that the

320 Lessepsian migrant $S$. chrysotaenia has acquired six native parasite species in the Mediterranean

321 Sea. Four of those species were found in our survey in Tunisian coastal waters and a fifth species 
322 had been noted in S. chrysotaenia elsewhere in the Mediterranean Sea (Table 2). We consider

323 these acquired parasite species to be native species from the Mediterranean Sea due to the

324 following reasons. The digenean Lecithochirium sp. has not been reported from the invasive $S$.

325 chrysotaenia, neither in the Mediterranean Sea nor in the Red Sea (Fischthal, 1982; Nahhas, Sey

$326 \&$ Nakahara, 2006). Given the complex life cycle of the Hemiuridae that need at least one

327 intermediate host species, and the fact that this genus now contains at least more than 100

328 species (Surekha \& Lakshmi, 2005) which at least 10 are reported from Mediterranean Sea with

329 scarcely life cycles (Table 3) and that the genus Lecithochirium is very specific to its first

330 intermediate gastropod host (Gibson \& Bray 1994), Lecithochirium sp. is most likely of

331 Mediterranean origin and has been acquired after the introduction of S. chrysotaenia to the

332 Mediterranean Sea. Specimens of the copepod Caligus sp. reported from S. chrysotaenia were in 333 poor condition and their identification to the species level was impossible. According to the

334 literature, no caligids were collected from S. chrysotaenia in the Red Sea but these parasitic 335 copepods have been recorded in native Mediterranean fish (Benmansour \& Ben Hassine, 1998;

336 Raibaut, Combes \& Benoit, 1998). Although many species are highly host specific there are also 337 many Caligus species with low host specificity (Yuniar, Palm \& Walteret, 2007), making a host

338 switch to the invasive host likely. However, further studies will be needed to ascertain the native 339 status of Caligus individuals found on the invasive host. Annelids of the family Piscicolidae are 340 considered to be generalists with a broad host specificity and are regularly reported from many 341 native fish hosts from Tunisian coasts and the Mediterranean Sea in general (Châari \& Neifar,

342 2015). According to the literature, no gnathiids were reported previously from $S$. chrysoteania in 343 the Red Sea. In contrast, this isopod genus is very common in the Mediterranean Sea and along 344 the Tunisian coasts, particularly on the skin of Sphyraenidae host species so that it is most likely 
345 native to the area. However, the native status of gnathiids found on the invader. The native

346 Cymothoid Anilocra physodes has been reported from many native hosts of the Mediterranean

347 Sea (Innal et al., 2007) and was only observed from the invasive fish S. chrysotaenia off Turkish

348 (Innal et al., 2007). Finally, the trematode Bucephalus labracis, which was not found in the

349 Lessepsian migrant elsewhere in the Mediterranean Sea (Fischhal, 1982), is considered to be

350 native as it uses a native bivalve (Ruditapes decussatus) as first intermediate host, a native fish

351 (Atherina boyeri) as second intermediate host and a native fish (Dicentrarchus labrax) as

352 definitive host (Paggi \& Orecchia (1965); Maillard (1976); Gargouri-Ben Abdallah \& Maamouri

353 (2005); Dhrif et al., 2015). The acquisition of these native parasites may generally have

354 potentially adverse effects naïve invasive host species, but also on native species, as the invasive

355 additional hosts can potentially elevate infection levels in native species via parasite spill back.

356 However, whether significant parasite spillback occurs in Tunisian waters remains to be studied.

357

358

359

360

361

362

363

364

365

366

367

\section{Cross-species comparison}

Our comparison of parasite infections in the Lessepsian migrant with the native congeneric Sphyraena sphyraena revealed considerable qualitative and quantitative differences between the parasite communities of the two fish species. The native fish was infected with six parasite species in Tunisian coastal waters and three additional species have been described elsewhere in the Mediterranean Sea (Table 2). Of all these parasite species, only one was shared with the invasive fish host, the presumably native isopod Gnathia sp.. As only larval stages of gnathiid parasite can infect fish and all larvae are morphologically very similar, identification to species level was not possible. Native Gnathia species have been reported from the study area (Châari \& Neifar, 2015) and we assume that the species found in our study is native but without 
368 further genetic work the native-invasive status in the invader cannot be fully clarified.

369 Interestingly, none of the parasites that were co-introduced with the Lessepsian migrant has been

370 found to infect the native congeneric host species. While the total number of parasite species

371 found in the two fish hosts in the Mediterranean Sea was similar (nine in the invasive and ten in

372 the native fish), the mean number of parasite species found in an individual fish was significantly

373 higher in the native compared to the invasive fish. Although the rarefaction analyses suggested

374 that further sampling would likely reveal more rare parasite species for each fish host, this

375 general pattern of a lower richness of the more common parasite species in the invasive host

376 species would remain at higher sampling efforts. In general, the parasite fauna of the invasive

377 fish was mainly composed of generalist native parasites acquired in the new environment and

378 one co-introduced parasite species, while the parasite community in native fish included more

379 specialist parasites. This is consistent with the general idea that invasive hosts often lose specific

380 parasites (especially with complex life cycles) in the course of the introduction and acquire

381 mainly native generalist parasites in the new range (Blakeslee, Fowler \& Keogh, 2013; Lymbery

382 et al., 2014).

383 In addition to parasite species richness, also total parasite prevalence (parasite infection

384 status in the models) and total infection intensity were generally higher in the native than in the

385 invasive fish. Hence, despite the acquisition of native parasites by the invasive host $S$.

386 chrysotaenia, the native $S$. sphyraena still showed higher total infection levels. This suggests that

387 the invasive host is experiencing lower parasite infection levels compared with the native host

388 species. Several factors may explain the lower infection levels of the invasive compared to the

389 native host species. First, the relatively small size of the invasive fish (20-25 cm length)

390 compared to the native fish $(30-60 \mathrm{~cm})$ may cause a space constraint and reduce exposure of the 
391 invasive fish to native parasites. However, the lack of a significant effect of fish size on infection

392 levels in our analyses suggests that body size may only play a minor role. Second, differences in

393 the feeding behaviour of the two fish hosts might explain why their parasite infection levels are

394 different. While the invasive $S$. chrysotaenia narrows its food spectrum to pelagic fish species,

395 the native $S$. sphyraena extended their feeding to supra-benthic species (Kalogirou et al., 2012).

396 The broader food spectrum of the native fish may result in a relative higher exposure to parasites.

397 Third, host suitability of the two fish species may differ and in particular invasive hosts may be

398 less suitable for native parasites due to compatibility issues. Finally, phylogenetic niche

399 conservatism (Wiens \& Graham, 2005; Mouillot et al., 2006) and a variety ecological factors

400 such as microhabitat use and life history strategies (Poulin, 2010) may play a role.

401 The presumably native isopod Gnathia sp. was the only parasite genus shared by the two

402 fish hosts in Tunisian coastal waters, with a higher prevalence and intensity in the native $S$.

403 sphyraena than in the invasive $S$. chrysotaenia. However, for both fish species there was only a 404 single record (at location 1 in the invasive host and at location 7 in the native host), 405 compromising a formal statistical comparison, rendering a solid discussion on the subsequent 406 host and parasite populations.

407

408

409 Conclusion

410 Our study found evidence for the loss of parasite species of the Lessepsian migrant in the course

411 of the introduction as well as for co-introduction of parasites and the acquisition of native

412 parasites. These results suggest that the Lessepsian migrant has the potential to affect native fish 
413 hosts by altering the population dynamics of native parasite species via parasite release, parasite

414 co-introduction and acquisition of native parasites, resulting in increased infection levels in

415 native hosts. They further suggest that the lower infection levels in the invasive host may give

416 them a potential competitive advantage over native hosts. Further studies will be needed to

417 investigate the resulting effects on native parasite dynamics and well as on native fish stocks.

418 This study demonstrated that community studies or cross-species comparisons such as the one

419 presented here, are valuable tools to identify the role of metazoan parasite in Lessepsian

420 migration.

421

422 Acknowledgments

423 We thank Dr. Hela Derbel for her useful comments on parasite identification and all fishermen

424 for their help during the fish sampling. In addition, we thank Dr. Jean-Lou Justine, Dr. Kenneth

425 MacKenzie and one anonymous reviewer for their useful comments on an earlier draft of our

426 manuscript.

427

428

429

430

431

432 References 
433 Allam SM, Faltas SN, and Ragheb E. 2005. Stock assessment of Barracudas, genus Sphyraena,

434

435

436

437

438

439

440

441

442

443

444

445

446

447

448

449

450

451

452

453

along the Egyptian Mediterranean Coast. Egyptian Journal of Aquatic Research 31: 281292.

Bakopoulos V, Karoubali I, and Diakou A. 2017. Parasites of the Lessepsian invasive fish Lagocephalus sceleratus (Gmelin 1789) in the eastern Mediterranean Sea. Journal of Natural History 51: 421-434. DOI: 10.1080/00222933.2017.1279690

Benmansour B, and Ben Hassine OK. 1998. Preliminary analysis of parasitic copepod species richness among coastal fishes of Tunisia. Monitore zoologico italiano. 65: 341-344 DOI $10.1080 / 11250009809386844$

Berland B.(1961). Nematodes from some Norwegian marine fishes. Sarsia 2: 1- 50.

Bilecenoglu M, Alfaya JEF, Azzurro E, Baldacconi R, Boyaci YO, Circosta V, Compagno LJV, Coppola F, Deidun A, Durgham H, Durucan F, Ergüden D, FernándezÁlvarez FÁ, Gianguzza P, Giglio G, Gökoğlu M, Gürlek M, Ikhtiyar S, Kabasakal H, Karachle PK, Katsanevakis S, Koutsogiannopoulos D, Lanfranco E, Micarelli P, Özvarol Y, Peña-Rivas L, Poursanidis D, Saliba J, Sperone E, Tibullo D, Tiralongo F, Tripepi S, Turan C, Vella P, Yokeş MB, Zava B. 2013. New Mediterranean marine biodiversity records (December, 2013). Mediterranean Marine Science 14: 463-480 DOI 10.12681/mms.676

Blakeslee AMH, Fowler AE, and Keogh CL. 2013. Marine invasion and parasite escape: updates and new perspectives. Advances in Marine Biology. 66: 87-169 DOI 10.1016/B978-0-12-408096-6.00002-X 
454 Boussellaa W, Boudaya L, Derbel H, and Neifar L. 2016. A new record of the Lessepsian fish 455 Etrumeus golanii (Teleostei: Clupeidae) in the Gulf of Gabes, Tunisia, with notes on its

456

457

458

459

460

461

462

463

464

465

466

467

468

469

470

471

472

473

474 parasites. Cahier de Biologie Marine 57: 389-395 DOI 10.21411/CBM.A.843F287A

Bradai MN, Saidi B, Ghorbel M, Bouain A, Guelorget O, and Capape C. 2002. Observations sur les requins du golfe de Gabès (Tunisie méridionale, Méditerranée centrale). Mesogée 60: 61-77.

\section{Chaabane A, Justine J-L, Gey D, Bakenhaster MD, and Neifar L. 2016a.} Pseudorhabdosynochus sulamericanus (Monogenea, Diplectanidae), a parasite of deepsea groupers (Serranidae) occurs transatlantically on three congeneric hosts (Hyporthodus spp.), one from the Mediterranean Sea and two from the western Atlantic. PeerJ 4:e2233. DOI 10.7717/peerj.2233

Chaabane A, Neifar L, Gey D, and Justine J-L. 2016b. Species of Pseudorhabdosynochus (Monogenea, Diplectanidae) from groupers (Mycteroperca spp., Epinephelidae) in the Mediterranean and Eastern Atlantic Ocean, with special reference to the "beverleyburtonae group" and description of two new species. PLOS ONE 11: e0159886. DOI 10.1371/journal.pone.0159886

Châari M, and Neifar L. 2015. Parasitic infections in the Mediterranean needle fish Tylosurus acus imperialis (Teleostei: Belonidae) off Tunisian coast. Journal of Coastal Life Medicine 3: 673-676 DOI 10.12980/jclm.3.2015j5-78

Chao A. 2005. Species richness estimation. In: Balakrishnan N, Read CB, Vidakovic B, eds. Encyclopedia of statistical sciences. Wiley: New York, 7909-7916. 
475

476

477

478

479

480

481

482

483

484

485

486

487

488

489

490

491

492

493

494

495

496

497

Colautti RI, Ricciardi A, Grigorovich IA, and MacIsaac HJ. 2004. Is invasion success

explained by the enemy release hypothesis? Ecology Letters 7:721-733 DOI

10.1111/j.1461-0248.2004.00616.x

Colwell RK. 2013. EstimateS: Statistical estimation of species richness and shared species from samples. Version 9. User's Guide and application published at: http://purl.oclc.org/estimates.

Dang C, Montaudouin X, Bald J, Jude F, Raymond N, Lanceleur L, Paul-Pont I, and CaillMilly N. 2009. Testing the enemy release hypothesis: trematode parasites in the nonindigenous Manila clam Ruditapes philippinarum. Hydrobiologia 630: 139-148 DOI $10.1007 / \mathrm{s} 10750-009-9786-9$

Daszak P, Cunningham AA, and Hyatt AD. 2000. Emerging infectious diseases of wildlife: threats to biodiversity and human health. Science 287: 443-449 DOI $10.1126 /$ science. 287.5452 .443

Dhrif E, Antar R, Abidli S, and Gargouri L. 2015. Digenean larvae parasitizing Ruditapes decussatus (Bivalvia) from Tunisian coasts. Helminthologia 52: 104-112 DOI 10.1515/helmin-2015-0019

Diamant A. 1989. Lessepsian migrants as hosts: a parasitological assessment of rabbitfish Siganus luridus and S. rivulatus (Siganidae) in their original and new zoogeographical regions. In: Spanier E, Steinberger Y, Lurin M, eds. Environmental quality and ecosystem stability: Environmental Quality ISEEQS Pub, Jerusalem, Israel. 4: 187-194.

Diamant A. 2010. Red-Med immigration: a fish parasitology perspective, with special reference to Mxyxosporea. In: Golani D, Appelbaum-Golani B, eds. Fish Invasions of the Mediterranean Sea: Change and Renewal. Pensoft Publishers: Sofia-Moscow, 85-97. 
498

499

500

501

502

503

504

505

506

507

508

509

510

511

512

513

514

515

516

517

518

El-Rashidy HH, and Boxshall GA. 2012. Bomolochid copepods (Crustacea: Copepoda: Bomolochidae) parasitizing immigrant and native barracuda (Actinopterygii: Sphyraenidae) caught off the Egyptian Mediterranean coast. Zoosymposia 8: 20-28 DOI 10.11646/zoosymposia.8.1.5

El-Shahawy IS, and Desouky ARY. 2010. Myripristis murdjan (Beryciformes: Holocentridae) a new host record for Cymothoa indica (Crustacea, Isopoda, Cymothoidae). Acta Adriatica 51: 103-110.

Elton CS. 1958. The ecology of invasions. Methuen: London, UK.

Euzet L. 1994. Order Tetraphyllidea Carus, 1863. In: Khalil LF, Jones A and Bray RA, ed. Keys to the cestode parasites of vertebrates. CAB International, Wallingford, U.K., 149-194.

Euzet L, and Trilles J-P. 1960. Sur deux Monogènes nouveaux de Sphyraena sphyraena (L.) (Teleostei Sphyraenidae). Bulletin de la Société Zoologique de France. 85: 189-198.

Fischthal JH. 1982. Additional records of digenetic trematodes of marine fishes from Israel's Mediterranean coast. Proceedings of the Helminthological Society of Washington 49: 3444.

Fisher W, Schneider M, and Bauchot ML. 1987. Fiches FAO d'identification des espèces pour les besoins de la pêche (Révision 1). Méditerranée et Mer Noire. Zone de pêche 37. Vertébrés. Rome FAO 2: 1-1045.

Forsyth DM, and Duncan RP. 2001. Propagule size and the relative success of exotic ungulate and bird introductions to New Zealand. The American Naturalist 157: 583-595 DOI $10.1086 / 320626$ 
519 Galaktionov K, and Dobrovolskij AA. 2003. The biology and evolution of trematodes: An

520 essay on the biology, morphology, life cycles, transmissions, and evolution of digenetic

521 trematodes. Springer, Dordrecht, Netherlands.

522 Galil BS, and Innocenti G. 1999. Notes on the population structure of the portunid crab Charybdis longicollis Leene, parasitized by the rhizocephalan Heterosaccus dollfusi Boschma, off the Mediterranean coast of Israel. Bulletin of Marine Science 64: 451-463.

Gargouri M, and Maamouri F. 2005. The life cycle of Bucephalus labracis Paggi and Orecchia, 1965 (Digenea, Bucephalidae), a parasite of Dicentrarchus labrax in Tunisia. Bulletin of the European Association of Fish Pathologists 25: 297-302.

Gendron AD, Marcogliese DJ, and Thomas M. 2012. Invasive species are less parasitized than native competitors, but for how long? The case of the round goby in the Great Lakes-St. Lawrence Basin. Biological Invasions 14: 367-384 DOI DOI 10.1007/s10530-011-0083-

Georgiev BB, Sanchez MI, Vasileva GP, Nikolov, PN, and Green AJ. 2007. Cestode parasitism in invasive and native brine shrimps (Artemia spp.) as a possible factor promoting the rapid invasion of A. franciscana in the Mediterranean region. Parasitology Research 101: 1647-1655 DOI 10.1007/s00436-007-0708-3

Gibson DI, and Bray RA. 1994. The evolutionary expansion and host-parasite relationships of the Digenea. International Journal for Parasitology 24: 1213-1226 DOI 10.1016/00207519(94)90192-9

Gibson DI, Jones A, and Bray RA. 2002. Keys to the Trematoda, Vol. 1. CABI Publishing: Wallingford, UK DOI 10.1016/S0035-9203(03)90052-6 
541 Goedknegt MA, Havermans J, Waser AM, Luttikhuizen PC, Perdomo EV, Camphuysen K

542 (CJ), van der Meer J, and Thieltges DW. 2016. Parasites and marine invasions:

543 Ecological and evolutionary perspectives. Journal of Sea Research 113: 11-27 DOI

$544 \quad 10.1016 /$ j.seares.2015.12.003

545 Goedknegt MA, Havermans J, Waser AM, Luttikhuizen PC, Vellila E, Camphuysen K

546 (CJ), Van der Meer J, and Thieltges DW. 2017. Cross-species comparison of parasite

547 richness, prevalence, and intensity in a native compared to two invasive brachyuran

$548 \quad$ crabs. Aquatic Invasions 12: 201-212 DOI 10.3391/ai.2017.12.2.08

549 Golani D, and Ben Tuvia A. 1995. Lessepsian migration and the Mediterranean fisheries of

550

551 Palestine. In: Armantrout NB, ed. Conditions of the world's aquatic habits. Proceedings

552

553

554

555

556

557

558

559

560

561

562

563 of the World Fishery Congress. New Delhi, India. 279-289.

Gotelli NJ, and Colwell RK. 2001. Quantifying biodiversity: procedures and pitfalls in the measurement and comparison of species richness. Ecology Letters 4: 379-391 DOI 10.1046/j.1461-0248.2001.00230.x

Innal D, Kirkim F, and Erk'akan F. 2007. The parasitic isopods, Anilocra frontalis and Anilocra physodes (Crustacea; Isopoda) on some marine fish in Antalya Gulf, Turkey. Bulletin of the European Association of Fish Pathologists 27: 239-241.

Kabata Z. 2003. Copepods Parasitic on Fishes. In: Crothers JH, Hayward PJ, eds. Synopsis of British Fauna (New Series), Vol. 47 (revised). The Linnean Society \& The Estuarine \& Coastal Sciences Association, London, 274 pp.

Kalogirou S, Mittermayer F, Pihl L, and Wennhage H. 2012. Feeding ecology of indigenous and non-indigenous fish species within the family Sphyraenidae. Journal of Fish Biology 80: 2528-2548 DOI 10.1111/j.1095-8649.2012.03306.x 
564 Keane RM, and Crawley MJ. 2002. Exotic plant invasions and the enemy release hypothesis.

565 Trends in Ecology \& Evolution 17: 164-170 DOI 10.1016/S0169-5347(02)02499-0

566 Kelly DW, Paterson RA, Townsend CR, Poulin R, and Tompkins DM. 2009. Parasite

567 spillback: A neglected concept in invasion ecology? Ecology 90: 2047-2056 DOI

$568 \quad 10.1890 / 08-1085.1$

569 Kritsky DC, Jiménez-Ruiz FA, and Sey O. 2000. Diplectanids (Monogenoidea:

570 Dactylogyridea) from the gills of marine fishes of the Persian Gulf off Kuwait.

$571 \quad$ Comparative Parasitology 67: 145-164.

572 Looss A. 1899. Weitere Beiträge zur Kenntnis der Trematoden-Fauna Aegyptens, zugleich

573

574 versuch einer natürlichen Gliederung des Genus Distomum Retzius. Zoologische Jabrbucher 12: 521-784.

Lymbery AJ., Morine M., Kanani HG., Beatty SJ., and Morgan DL. 2014. Co-invaders: The effects of alien parasites on native hosts. International Journal for Parasitology: Parasites and Wildlife 3: 171-177 DOI 10.1016/j.ijppaw.2014.04.002

Maillard C. 1976. Distomatoses de poissons en milieu lagunaire. Dr. Sci. Thesis. Montpellier: Université des Sciences et Techniques du Languedoc.

Merella P, Pais A, Follesa MC, Farjallah S, Mele S, Piras MC, and Garippa G. 2016.

Mouillot D, Krasnov BR, Shenbrot GI, Gaston KJ, and Poulin R. 2006. Conservatism of host specificity in parasites. Ecography 29: 596-602 DOI 10.1111/j.09067590.2006.04507.x 
587 Nahhas FM, Sey O, and Nakahara G. 2006. Digenetic trematodes of marine fishes from the

588

589

590

591

592

593

594

595

596

597

598

599

600

601

602

603

604

605

606

607

608

Arabian Gulf off the coast of Kuwait. Family Bucephalidae Poche, 1907, and the description of a new species. Helminthologia 43: 147-157 DOI 10.2478/s11687-0060028-7

Neifar L. 1995. Contribution à l'étude de la biodiversité des monogènes parasites de poissons du secteur nord-est de la Tunisie. Mémoire de Diplôme d'Etudes Approfondies. Université de Tunis II.

Neifar L, and Euzet L 2007. Five new species of Pseudorhabdosynochus (Monogenea: Diplectanidae) from the gills of Epinephelus costae (Teleostei: Serranidae). Folia Parasitologica 54: 117-128 DOI 10.14411/fp.2007.017

Oliver G. 1987. Les Diplectanidae Bychowsky, 1957 (Monogenea, Monopisthocotylea, Dactylogyridea). Systématique. Biologie. Ontogénie. Écologie. Essai de phylogenèse. Dr. Sci. Thesis. Université de Montpellier. DOI: 10.6084/m9.figshare.1295274

Paggi L, and Orecchia P. 1965. Su un nuovo trematode parassita dell'intestino di Morone labrax: Bucephalus labracis n. sp. Parassitologia 7: 69-74.

Pérez-del-Olmo A, Kostadinova A, and Gibson DI. 2016. The Mediterranean: high discovery rates for a well-studied trematode fauna. Systematic Parasitology 93: 249-256 DOI $10.1007 / \mathrm{s} 11230-016-9626-\mathrm{Z}$

Petter AJ, and Maillard C. 1988. Larves d'Ascarides parasites de poissons en Méditerranée occidentale. Bulletin du Muséum national d'histoire naturelle. Section A, Zoologie, biologie et écologie animales. Muséum national d'Histoire naturelle: 4e série, tôme 10: 347-369. 
609 Por FD. 1978. Lessepsian migration: the influx of Red Sea biota into the Mediterranean by way 610 of the Suez Canal. Ecological studies. Springer-Verlag, Berlin, Germany.

611 Poulin R, and Cribb TH. 2002. Trematode life cycles: short is sweet? Trends in Parasitology 612 18: 176-183.

613 Poulin R, and Morand S. 2004. Parasite Biodiversity. Smithsonian Books, Washington DC, 614 USA DOI 10.1017/S003118200521908X

615

616

Poulin R. 2010. Network analysis shining light on parasite ecology and diversity. Trends in Parasitology 26: 492-498 DOI 10.1016/j.pt.2010.05.008

617

618

619

620

621

622

623

624

625

626

627

628

629

Prenter J, MacNeil C, Dick JTA, and Dunn AM. 2004. Roles of parasites in animal invasions. Trends in Ecology \& Evolution 19: 385-390 DOI 10.1016/j.tree.2004.05.002

Raibaut A, Combes C, and Benoit F. 1998. Analysis of the parasitic copepod species richness among Mediterranean fish. Journal of Marine Systems 15: 185-206 DOI 10.1016/S09247963(97)00079-1

Ramdane Z, Bensouilah MA, and Trilles J-P 2009. Étude comparative des crustacés isopodes et copépodes ectoparasites de poissons marins algériens et marocains. Cybium 33: 123131.

R Development Core Team 2016. R: A language and environment for statistical computing. $R$ Foundation for Statistical Computing, Vienna, Austria. URL https://www.Rproject.org/

Relini M, and Orsi Relini L. 1997. The two species of barracuda (Sphyraenidae) in the western mediterranean. Cybium 21: 216-222. 
630 Roche DG, Leung B, Franco EFM, and Torchin ME 2010. Higher parasite richness,

631

632

633

634

635

636

637

638

639

640

641

642

643

644

645

646

647

648

649

650

651

abundance, and impact in native versus introduced cichlid fishes. International Journal for Parasitology 40: 1525-1530 DOI 10.1016/j.ijpara.2010.05.007

Rouget M, and Richardson DM. 2003. Inferring process from pattern in plant invasions: a semi mechanistic model incorporating propagule pressure and environmental variables. The American Naturalist 162: 713-724.

Santos CP, Mourão ED, and Cárdenas MQ. 2001. Pseudempleurosoma gibsoni n. sp., a new ancyrocephalid monogenean from Paralonchurus brasiliensis (Sciaenidae) from off the southeastern coast of Brazil. Memórias do Instituto Oswaldo Cruz 96: 215-219 DOI 10.1590/S0074-02762001000200013.

Spicer IJ. 1931. Report of the Department of Agriculture and Forests for the years 1927-30. Jerusalem: Printing Office, Russian Building, 159-160.

Surekha P, and Lakshmi C.V. 2005. Lecithochirium testelobatus n. sp. (Digenea: Hemiuridae) from the Lizard fish, Saurida undosquamis from Andhrapradesh Coast. Journal of Parasitic Diseases 29: 143-146

Theisen S, Palm HW, Al-Jufaili SH, and Kleinertz S. 2017. Pseudempleurosoma haywardi $\mathrm{sp.}$ nov. (Monogenea: Ancyrocephalidae (sensu lato) Bychowsky \& Nagibina, 1968): An endoparasite of croakers (Teleostei: Sciaenidae) from Indonesia. PLoS ONE 12: e0184376. DOI 10.1371/journal.pone.0184376

Torchin ME, Lafferty KD, and Kuris AM. 2001. Release from parasites as natural enemies: increased performance of a globally introduced marine crab. Biological Invasions 3: 333345 DOI 10.1023/A:1015855019360 
652 Torchin ME, Lafferty KD, and Kuris AM. 2002. Parasites and marine invasions. Parasitology

$653 \quad$ 124: $137-15110.1017 /$ S0031182002001506

654 Torchin ME, Lafferty KD, Dobson AP, McKenzie VJ, and Kuris AM. 2003. Introduced

655 species and their missing parasites. Nature 421: 628-630 DOI 10.1038/nature01346

656 Torchin ME, and Mitchell CE. 2004. Parasites, pathogens, and invasions by plants and

657

animals. Frontiers in Ecology and the Environment 2: 183-190 DOI 10.1890/1540-

658 9295(2004)002[0183:PPAIBP]2.0.CO;2

659

660

661

Townsend S. 2009. Incorporating sustainable practices for zoos and aquariums: a Triple Bottom Line approach. International Zoo Yearbook 43: 53-63 DOI 10.1111/j.1748-

662

Trilles JP, and Bariche M 2006. First record of the Indo-Pacific Cymothoa indica (Crustacea, 663 Isopoda, Cymothoidae), a Lessepsian species in the Mediterranean Sea. Acta

664 Parasitologica 51: 223-230 DOI 10.2478/s11686-006-0035-3

665

666

667

668

669

670

671

672

673 1090.2008.00065.x

$1090.2008 .00065 . x$

Vignon M, and Sasal, P. 2010. The use of geometric morphometrics in understanding shape variability of sclerotized haptoral structures of monogeneans (Platyhelminthes) with insights into biogeographic variability. Parasitology International 59: 183-191 DOI

10.1016/j.parint.2010.01.006

Wadie WF, and Riskallah SI 2001. Fisheries for the genus Sphyraena (Perciformes, sphyraenidae) in the southeastern part of the Mediterranean Sea. Pakistan Journal of Science 10: 21-34.

Walther BA, and Morand S. 1998. Comparative performance of species richness estimation methods. Parasitology 116: 395-405. 
674 Whitehead PJP, Bauchot ML, Hureau JC, Nielsen J, and Tortonese E, eds. 1984. Fishes of 675 the North-eastern Atlantic and the Mediterranean. UNESCO, Paris, France.

676 Wiens JJ, and Graham CH. 2005. Niche conservatism: integrating evolution, ecology, and 677 conservation biology. Annual Review of Ecology, Evolution, and Systematics 36: 519539. DOI 10.1146/annurev.ecolsys.36.102803.095431

679 680

Wonham MJ, Carlton JT, Ruiz GM, and Smith LD. 2000. Fish and ships: relating dispersal frequency to success in biological invasions. Marine Biology 136: 1111-1121.

Yamaguti S. 1953. Parasitic worms mainly from Celebes. Part. 2. Monogenetic Trematodes of fishes. Acta Medica Okayama 8: 204-256.

Yuniar AT, Palm HW, and Walter T. 2007. Crustacean fish parasites from Segara Anakan Lagoon, Java, Indonesia. Parasitology Research 100: 1193-1204 DOI 10.1007/s00436-006-0391-9

Zenetos A, Meriç E, Verlaque M, Galli P, and Boudouresque CF. 2008. Additions to the annotated list of marine alien biota in the Mediterranean with special emphasis on Foraminifera and Parasites. Mediterranean Marine Science 9: 119-166 DOI $10.12681 / \mathrm{mms} .146$

Zouari-Ktari R, Bradai MN, and Bouain A. 2009. Reproduction and growth of the Yellowstripe Barracuda Sphyraena chrysotaenia Klunzinger 1884, in Central Mediterranean. Reviews in Fisheries Science 17: 485-493

DOI $10.1080 / 10641260903082471$ 


\section{Table $\mathbf{1}$ (on next page)}

Information on the sampling design of fish hosts collected for this study in Tunisian coastal waters.

Given are the location numbers used in Figure 1, location name, geographic coordinates, sampling dates and sample sizes (per sex) for the two fish host species (Sphyraena sphyraena and Sphyraena chrysotaenia). 
1

2

\begin{tabular}{|c|c|c|c|c|c|c|c|}
\hline \multirow[t]{2}{*}{$\begin{array}{l}\text { Location } \\
\text { number }\end{array}$} & \multirow[t]{2}{*}{$\begin{array}{c}\text { Location } \\
\text { name }\end{array}$} & \multirow[t]{2}{*}{$\begin{array}{l}\text { Geographic } \\
\text { coordinates }\end{array}$} & \multirow[t]{2}{*}{$\begin{array}{c}\text { Sampling } \\
\text { dates }\end{array}$} & \multicolumn{2}{|c|}{$\begin{array}{c}\text { Sphyraena } \\
\text { sphyraena } \\
\text { (native) }\end{array}$} & \multicolumn{2}{|c|}{$\begin{array}{c}\text { Sphyraena } \\
\text { chrysotaenia } \\
\text { (invasive) }\end{array}$} \\
\hline & & & & Females & Males & Females & Males \\
\hline 1 & Sfax & $\begin{array}{l}34^{\circ} 44^{\prime} 26^{\prime \prime} \mathrm{N} \\
10^{\circ} 45^{\prime} 37^{\prime \prime} \mathrm{E}\end{array}$ & $\begin{array}{l}22 / 10 / 2012 \\
08 / 03 / 2013\end{array}$ & 3 & 3 & 9 & 9 \\
\hline 2 & Kerkennah & $\begin{array}{l}34^{\circ} 39^{\prime} 29^{\prime \prime} \mathrm{N} \\
11^{\circ} 04^{\prime} 07^{\prime \prime} \mathrm{E}\end{array}$ & $\begin{array}{l}10 / 02 / 2013 \\
10 / 03 / 2013 \\
10 / 09 / 2013\end{array}$ & 20 & 11 & 18 & 15 \\
\hline 3 & Skhira & $\begin{array}{l}34^{\circ} 17^{\prime} 57^{\prime \prime} \mathrm{N} \\
10^{\circ} 04^{\prime} 11^{\prime \prime} \mathrm{E}\end{array}$ & $\begin{array}{l}06 / 11 / 2014 \\
04 / 07 / 2015\end{array}$ & 10 & 8 & 7 & 10 \\
\hline 4 & Chebba & $\begin{array}{c}35^{\circ} 14^{\prime} 14^{\prime \prime} \mathrm{N} \\
11^{\circ} 6^{\prime} 54^{\prime \prime} \mathrm{E}\end{array}$ & $05 / 11 / 2012$ & 8 & 1 & 5 & 14 \\
\hline 5 & Zarat & $\begin{array}{l}33^{\circ} 39^{\prime} 59^{\prime \prime} \mathrm{N} \\
10^{\circ} 20^{\prime} 59^{\prime \prime} \mathrm{E}\end{array}$ & $07 / 02 / 2014$ & 6 & 1 & 15 & 6 \\
\hline 6 & Zarzis & $\begin{array}{l}33^{\circ} 30^{\prime} 14^{\prime \prime} \mathrm{N} \\
11^{\circ} 06^{\prime} 43^{\prime \prime} \mathrm{E}\end{array}$ & $\begin{array}{l}11 / 05 / 2015 \\
19 / 06 / 2015\end{array}$ & 11 & 6 & 9 & 7 \\
\hline 7 & Sayada & $\begin{array}{c}35^{\circ} 40^{\prime} 7^{\prime \prime} \mathrm{N} \\
10^{\circ} 53^{\prime} 32^{\prime \prime} \mathrm{E}\end{array}$ & $\begin{array}{l}07 / 02 / 2014 \\
03 / 06 / 2014\end{array}$ & 15 & 4 & 7 & 17 \\
\hline & & Total & & 73 & 34 & 70 & 78 \\
\hline
\end{tabular}




\section{Table 2 (on next page)}

Parasite species of Sphyraena sphyraena and Sphyraena chrysoteania found in this study and recorded in the literature.

Information on the life cycle and the invasive/native status in the Mediterranean Sea and occurrence in the two host species and regions (Mediterranean Sea and Red Sea). If quantitative data were available, mean prevalence and intensity $( \pm S E)$ in a host species and region are given. + denotes published records of specific parasite species in a host species in a region; $(+)$ denotes an assumed occurrence in a host species and region without published records. 


\begin{tabular}{|c|c|c|c|c|c|c|c|c|}
\hline $\begin{array}{l}\text { Parasite } \\
\text { taxa }\end{array}$ & Parasite species & $\begin{array}{l}\text { Life } \\
\text { cycle }\end{array}$ & Host specificity & $\begin{array}{l}\text { Status } \\
\text { Med Sea }\end{array}$ & $\begin{array}{c}\text { Sphyraena } \\
\text { sphyraena } \\
\text { (native range- } \\
\text { Med Sea) } \\
\end{array}$ & $\begin{array}{c}\text { Sphyraena } \\
\text { chrysotaenia } \\
\text { (invasive range - } \\
\text { Med Sea) }\end{array}$ & $\begin{array}{c}\text { Sphyraena } \\
\text { chrysotaenia } \\
\text { (native range } \\
\text { - Red Sea) }\end{array}$ & Reference \\
\hline Annelida & Piscicolid sp. & complex & generalist & native & & $0.7 \%(1 \pm 0)$ & & This study \\
\hline \multirow{4}{*}{ Copepoda } & Caligus sp. & direct & Specialist/generalist? & native & & $3.8 \%(1 \pm 0)$ & & This study \\
\hline & Bomolochus unicirrus & direct & specialist & native & $29 \%(2 \pm 0.1)$ & & & This study \\
\hline & $\begin{array}{l}\text { Nothobomolochus } \\
\text { denticulatus }\end{array}$ & direct & specialist & invasive & & + & $(+)$ & $\begin{array}{l}\text { El-Rashidy and Boxshall, } \\
2012\end{array}$ \\
\hline & Pennella filosa & complex & generalist & native & + & & & Ramdane et al. 2009 \\
\hline \multirow{5}{*}{ Digenea } & Lecithochirium sp. & complex & generalist & native & & $12.2 \%(1.4 \pm 0)$ & & This study \\
\hline & $\begin{array}{c}\text { Didymozoon } \\
\text { sphyraenae }\end{array}$ & complex & specialist & native & $85 \%(5.5 \pm 0.4)$ & & & This study \\
\hline & Bucephalus sphyraenae & complex & specialist & not present & & & + & Nahhas et al. 2006 \\
\hline & Bucephalus labracis & complex & specialist & native & & + & & Fischthal, 1982 \\
\hline & Plerurus digitatus & complex & generalist & native & + & & & Looss, 1899 \\
\hline \multirow{3}{*}{ Isopoda } & Gnathia sp. & complex & generalist & native & $0.9 \%(13 \pm 0.1)$ & $0.7 \%(2 \pm 0)$ & & This study \\
\hline & Cymothoa indica & complex & generalist & invasive & & + & $(+)$ & Trilles and Bariche, 2006 \\
\hline & Anilocra physodes & complex & generalist & native & & + & & İnnal et al. 2007 \\
\hline \multirow{4}{*}{ Monogenea } & Pseudempleurosoma sp. & direct & specialist & invasive & & $4 \%(1 \pm 0)$ & $(+)$ & This study \\
\hline & $\begin{array}{c}\text { Pseudolamellodiscus } \\
\text { sphyraenae }\end{array}$ & direct & specialist & not present & & & + & $\begin{array}{c}\text { Yamaguti, 1953; Kritsky et al. } \\
2000\end{array}$ \\
\hline & $\begin{array}{l}\text { Cotyloatlantica } \\
\text { mediterranea }\end{array}$ & direct & specialist & native & + & & & Euzet and Trilles, 1960 \\
\hline & Rhinecotyle crepitacula & direct & specialist & native & + & & & Euzet and Trilles, 1960 \\
\hline Nematoda & Anisakis sp. & complex & generalist & native & $1.9 \%(3 \pm 0)$ & & & This study \\
\hline $\begin{array}{c}\text { Total } \\
\text { species } \\
\text { richness }\end{array}$ & & & & & 10 & 9 & 5 & \\
\hline
\end{tabular}




\section{Table 3(on next page)}

Parasite species of the genus Lecithochirium recorded in the literature, with information on the life cycle (Intermediate host and Definitive host) in the Mediterranean Sea. 


\begin{tabular}{|c|c|c|}
\hline Parasites & Intermediate host & Definitive host \\
\hline $\begin{array}{c}\text { Lecithochirium fusiforme } \\
\text { Luhe, } 1901\end{array}$ & Gibbula cineraria & $\begin{array}{c}\text { Conger conger } \\
\text { Lophius piscatorius }\end{array}$ \\
\hline $\begin{array}{c}\text { Lecithochirium musculus } \\
\text { (Looss, 1907) }\end{array}$ & $\begin{array}{l}\text { Conger myriaster } \\
\text { Conger japonicus }\end{array}$ & $\begin{array}{c}\text { Anguilla anguilla } \\
\text { Trachurus trachurus } \\
\text { Serranus hepatus } \\
\text { Crenilabrus cinereus } \\
\text { Conger conger } \\
\text { Atherina Hepsetus } \\
\text { Serranus scriba }\end{array}$ \\
\hline $\begin{array}{c}\text { Lecithochirium physcon } \\
\text { Luhe, } 1901\end{array}$ & - & Lophius piscatorius \\
\hline $\begin{array}{l}\text { Lecithochirium rufoviride } \\
\text { (Rudolphi, 1819) }\end{array}$ & $\begin{array}{l}\text { Gibbula cineraria } \\
\text { Blennius pholis }\end{array}$ & Anguilla anguilla \\
\hline $\begin{array}{l}\text { Lecithochirium texanum } \\
\text { (Chandler, 1941) }\end{array}$ & - & Euthynnus alleteratus \\
\hline $\begin{array}{c}\text { Lecithochirium jaffense } \\
\text { Fischthal, } 1982\end{array}$ & Seriola dumerili & $\begin{array}{c}\text { Trachinotus ovatus } \\
\text { Epinephelus sp. } \\
\text { Echeneis naucrates } \\
\text { Pomatomus saltatrix } \\
\text { Gobius cobitus } \\
\text { Etrumeus golanii }\end{array}$ \\
\hline $\begin{array}{c}\text { Lecithochirium haifense } \\
\text { Fischthal, } 1980\end{array}$ & - & Atule djeddaba \\
\hline $\begin{array}{l}\text { Lecithochirium magnicaudatus } \\
\text { (Fischthal \& Kuntz, 1963) }\end{array}$ & - & $\begin{array}{c}\text { Saurida undosquamis } \\
\text { Labeo forskalii }\end{array}$ \\
\hline $\begin{array}{c}\text { Lecithochirium microstomum } \\
\text { Chandler, } 1935\end{array}$ & - & Trichiurus lepturus \\
\hline $\begin{array}{c}\text { Lecithochirium grandiporum } \\
\text { (Rudolphi,1819) }\end{array}$ & - & $\begin{array}{l}\text { Muraena helena } \\
\text { Lophius piscatorius } \\
\text { Conger conger } \\
\text { Saurida tumbil }\end{array}$ \\
\hline
\end{tabular}




\section{Figure 1}

Sampling locations (1-7) of the native Sphyraena sphyraena and the invasive Lessepsian migrant Sphyraena chrysotaenia in the central Mediterranean Sea (a) along the Tunisian coast (b) .

For location names, coordinates, sampling dates and sampling effort per species see Table 1. 


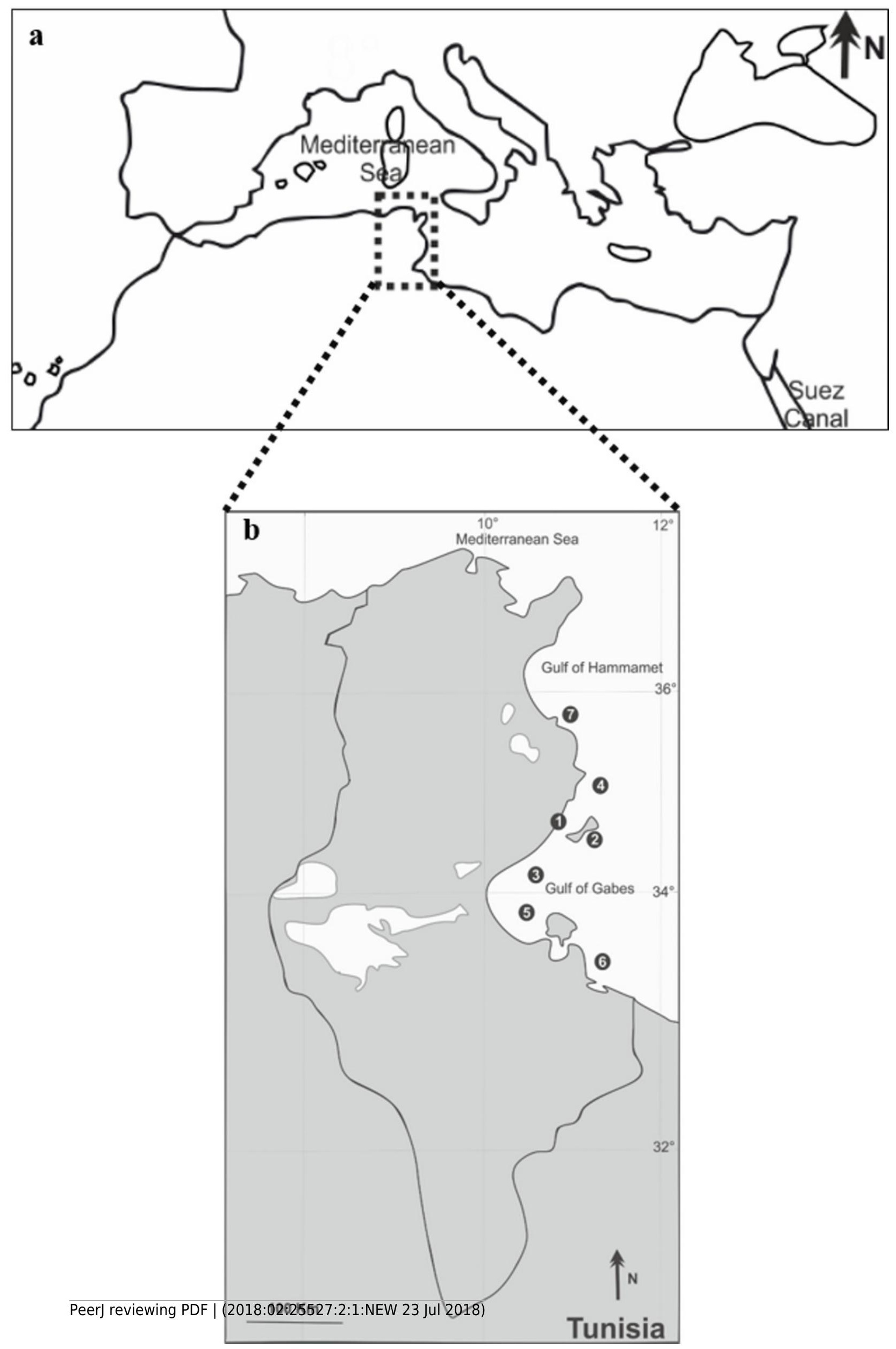


Figure 2

Rarefraction curves for parasite richness for a) the native fish Sphyraena sphyraena and b) the invasive Lessepsian migrant Sphyraena chrysotaenia.

Shown are the observed species richness accumulation curves $\left(\mathrm{S}_{\text {obs }}\right)$ which is the mean number of species among runs and the predicted number of species ( $\pm \mathrm{SE}$ ) based on the Chao2 estimator algorithm. 


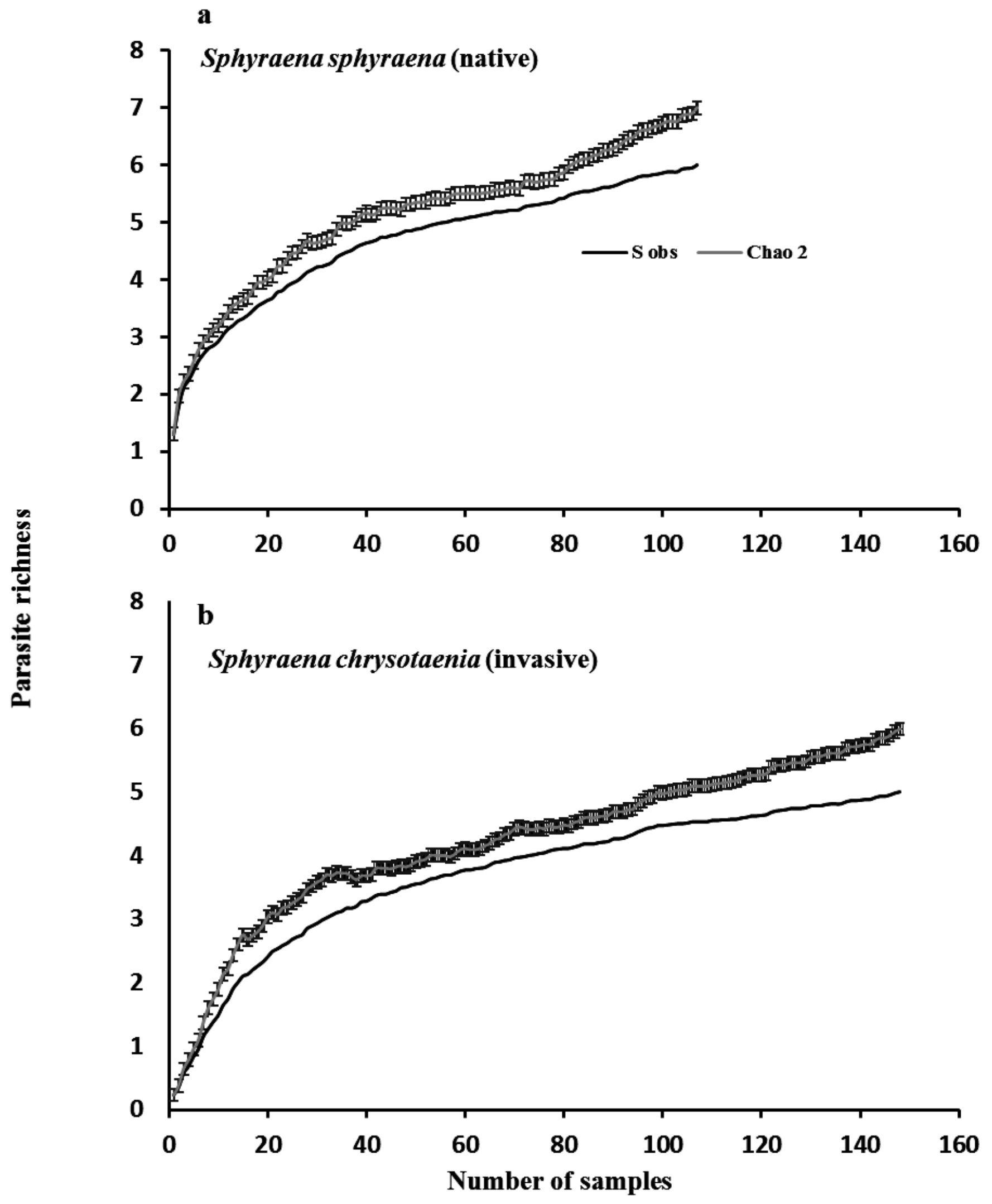


Figure 3

Mean parasite species richness per individual fish.

(including non-infected hosts; $\pm \mathrm{SE}$ ) at the seven locations in the native fish Sphyraena

sphyraena $(n=107)$ and the invasive congeneric Sphyraena chrysotaenia $(n=148)$.

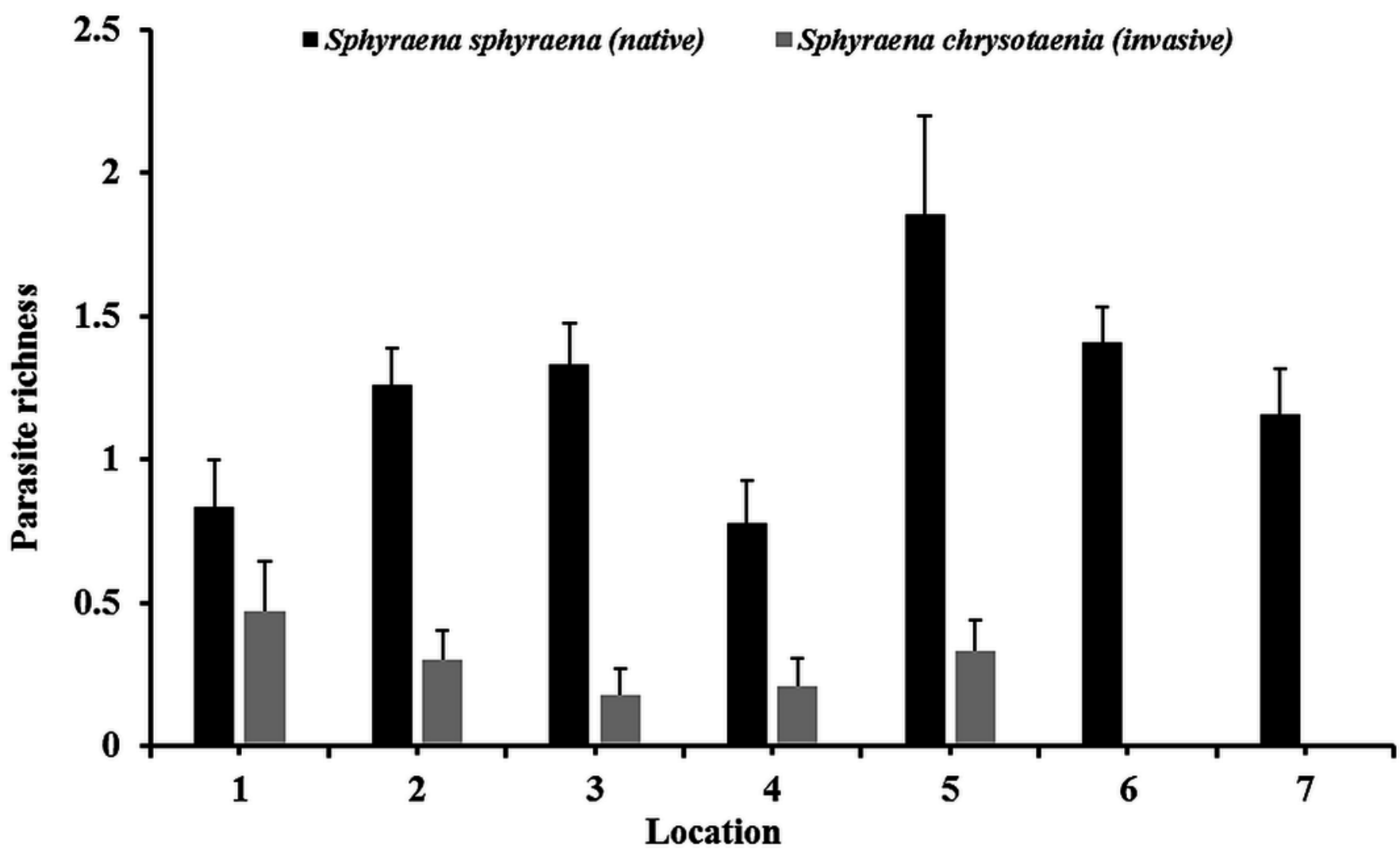




\section{Figure 4}

a) Mean total prevalence of all parasites in hosts and b) mean intensity of total parasite loads in native Sphyraena sphyraena and invasive Sphyraena chrysotaenia at the seven sampling locations.

Mean total prevalence (i.e. hosts infected by 1 or more parasite species); and mean intensity loads (i.e. sum of all parasite individuals found in a host) For sample size (n) per host species and location, see Table 1. 

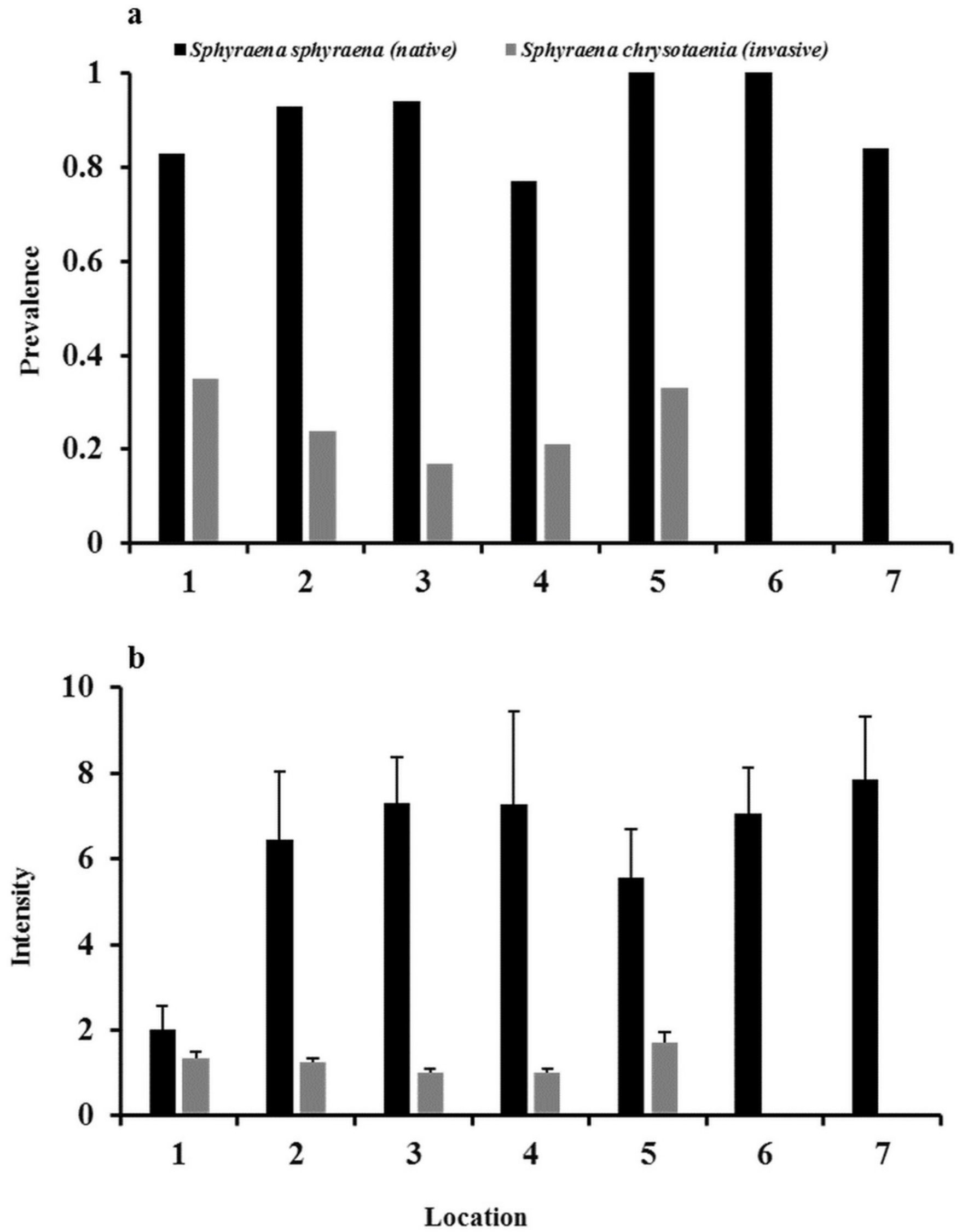